Waste Management, Volume 61, March 2017, pp. 608-616

DOI:10.1016/j.wasman.2016.10.036

\title{
Monetising the impacts of waste incinerators sited on brownfield land using the hedonic
} pricing method

Monica Rivas Casado ${ }^{a}$, Jan Serafini ${ }^{a}$, John Glen ${ }^{b}$ \& Andrew Angus ${ }^{\text {b* }}$

aSchool of Energy, Environment and Agrifood, Cranfield University, Cranfield, MK43 OAL, United Kingdom

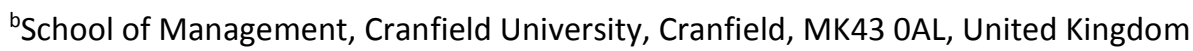

*Corresponding author: a.angus@cranfield.ac.uk, Tel.:01234750111 ext 4334

8

(1)

\section{ABSTRACT}

In England and Wales planning regulations require local governments to treat waste near its source. This policy principle alongside regional self-sufficiency and the logistical advantages of minimising distances for waste treatment mean that waste incinerators have been built close to, or even within urban conurbations. There is a clear policy need to balance the benefits of EfW against the negative externalities experienced by local residents in a European context. This study uses the Hedonic Pricing Method to estimate the monetary value of impacts associated with three incinerators. Once operational, the impact of the incinerators on local house prices ranged from approximately $0.4 \%$ to $1.3 \%$ of the mean house price for the respective areas. Each of the incinerators studied had been sited on previously industrialised land to minimise overall impact. To an extent this was achieved and results support the effectiveness of spatial planning strategies to reduce the impact on residents. However, negative impacts occurred in areas further afield from the incinerator, suggesting that more can

23 be done to minimise the impacts of incinerators. 
25 Keywords: hedonic pricing method; incinerator; willingness to pay; negative externalities

26 


\section{Introduction}

30 The waste hierarchy is the rationale that underpins most European waste legislation, such as

31 the European Waste Framework Directive 2008/98/EC (EU, 2008). The hierarchy is based on the

32 principle that prevention of waste is the most desirable form of waste management and

33 disposal of waste in landfill without energy recovery is the least. There are a range of other

34 management options between these polar opposites, such as incineration with energy

35 recovery, also known as Energy from Waste (EfW). When waste avoidance and recycling

36 opportunities are unfeasible EfW is the next best alternative.

37

In England and Wales compliance with European legislation has driven significant investment in waste management facilities that offer alternatives to landfill (Defra, 2014). In addition to the 30 incinerators currently operating in England and Wales (Defra, 2013), over 100 new

41 incinerators are in the proposal or planning stage (UKWIN, 2015). Two major guiding principles

42 of waste management strategy in England and Wales are that facilities should be located such

43 that: waste is managed or treated as close as possible to its source; and that the environmental 44 or social impacts of a waste management facility should be minimised (DCLG, 2015). These two 45 principles have the potential to conflict, given that those who create waste are those that must 46 be protected from the impacts of waste management. 
48 This conflict has given rise to notable public protests where incinerators have been proposed near residential areas (BBC, 2015; BBC, 2013; BBC, 2012). This opposition arises partly because of the nuisances and risks associated with waste incineration (COWI, 2000; Eshet et

51 al., 2005; Rabl et al., 2008; Defra, 2013). Incinerators share many of the same negative

52 externalities as landfills including noise, unpleasant odour, windblown litter, dust, vermin,

53 presence of seagulls, flies, traffic, visual intrusion and enhanced perception of health risks

54 among local residents (Havranek et al., 2009). Thus, while the decision to site an incinerator

55 requires a technical and spatial assessment it also remains a highly sensitive issue for local 56 residents.

57

58 Considering where to site EfW incinerators requires an analysis of all costs and benefits associated with waste incineration. While the benefits of incineration are largely tangible, such as the monetary value of electricity generated and number of jobs created, many of the

61 disamenities are not. To date, the literature has typically used the Hedonic Pricing Method

62 (HPM) to monetise the negative externalities of waste management. The HPM uses housing market data to estimate the price individuals are willing to pay for a non-marketed quality

64 (Lancaster et al., 1996), such as distance from a waste management site.

65

Most studies that investigate the impact of incinerators on house prices have focused on US sites. These results are unsuitable for use in a European policy context (Havranek et al. 2009) because of differences in environmental policy and property markets. This leaves an important 69 research gap. There is a clear policy need to balance the benefits of EfW against the negative 
87

\section{4}

85

externalities experienced by local residents in a European context. Such analysis helps policy makers identify instances where EfW offers clear gains in net present value and others where EfW is unsuitable and alternative waste management options should be considered.

To meet this research need, this paper uses the HPM to quantify the impact of three EfW incinerators in England. In particular, the study focuses on the effect that these waste management sites have on property prices at three development stages: planning, construction and operational. The analysis processes over 55,000 transactions over a 20 year period. To the authors' knowledge this is the first European study on incinerator negative externalities that adopts a HPM approach using such a large volume of data. Although this study focuses on sites in England, the results have relevance to other countries with duties to comply with EU Waste Regulations. This study also has international relevance, offering another comparison measurement of the cost of the negative externalities of incinerators, as well as an analysis of whether spatial planning provides a useful option for waste management.

\section{The impacts of EfW incinerators on house prices}

Compared with research estimating the negative externalities landfill sites, the negative

externalities of waste incineration have received less attention. The results of many

existing studies that monetise the negative externalities of incineration, such as Kiel and

1 McClain (1995a and 1995b) are based on outdated incinerator technology and hence resulting emissions have 
outdated incinerator technology and hence resulting emissions have improved significantly over the intervening period (HPA, 2009). Several other studies (Kohlhase, 1991; Deaton and Hoehnb, 2004; Kiel and Williams, 2007) focus on hazardous waste sites, which, owing to the intrinsic toxic characteristics of the waste are expected to generate stronger negative impacts on local properties relative to municipal and/or industrial waste processing sites. This study focuses entirely on municipal waste sites, which are more common, and as such the impact of the disposal of toxic waste is outside the scope of this paper.

All European empirical studies that investigate the cost of externalities associated with proximity to incinerators focus on UK sites. Pragnell (2003) used the HPM to assess the monetary impact of proximity to $10 \mathrm{UK}$ EfW incinerators. Their results show that incinerators had a negative effect on house prices up to $1.6 \mathrm{~km}$ from the incinerator. Between $0.4 \mathrm{~km}$ and $1.6 \mathrm{~km}$ the impact on house prices declined with increasing distance from the incinerator, eventually reaching zero at $1.7 \mathrm{~km}$. The results from Pragnell (2003) must be treated with caution. Firstly, the study only considers housing transactions in the fourth quarter of 2002. This is opposed to Kiel and McClain (1995a and 1995b), who use a continuous time series. Furthermore, the study assumes neighbourhood characteristics are homogeneous across different sites. Thus, the research excludes other factors, such as quality of schools or crime rates, which could affect house prices. Finally, the study uses data from the UK Land Registry transaction dataset. This dataset excludes some critical housing characteristics, such as, number of bedrooms and bathrooms, property and garden size, access to parking and garage, which can explain approximately $60 \%$ of price variance (Cambridge Econometrics, 2003). 
115 Havranek et al. (2009) focused on an EfW incinerator in Dudley, England. The study used a 116 choice experiment to estimate the impacts of noise, odour, visual intrusion and traffic. The

117 study found that participants had a low Willingness to Pay (WTP) to reduce the impact of the

118 incinerator's disamenities. However, the authors argue that the very small size of the

119 incinerator, the highly industrialised area in which it is sited and the fact that the facility has

120 existed for over 70 years are all factors that might have significantly affected the results of the

121 research. For all these reasons Havranek et al. (2009) concludes that the study offers limited

122 inferences for other UK incinerators.

124 Phillips et al. (2014) provides the most recent research on the impact of UK EfW incinerators on 125 property prices. They investigated three existing facilities that began operations between 2000 126 and 2004 , organising data into five $1 \mathrm{~km}$ radius bands from the centre of each site. The analysis 127 adopted an approach similar to the repeat sales method (OECD, 2013), only considering houses 128 that sold twice during the period: once before the facility was operational and once after. The 129 results show that houses around two of three incinerators (Kirklees and Chineham plants) 130 experienced an increase in price after the facility became operative. Property values within 1.2 $131 \mathrm{~km}$ from Marchwood incinerator, the largest and most visually intrusive of the facilities

132 examined by the study, were found to be lower after the facility became operative. However, 133 none of these results were statistically significant $(\alpha=0.05)$. Thus, all three incinerators were 134 found to have no effect on local house prices. 
136 Again, these results must be treated with caution. The repeat sales approach has some

137 limitations. Houses that sell twice during a given period could have some intrinsic

138 characteristics that differentiate them from houses that were only sold once (for instance, for

139 refurbishment), leading to a sample selection bias. Secondly, this technique significantly

140 decreases the number of available observations, thus reducing the robustness of the analysis.

141 The study researched house prices differentials associated with the proximity to an incinerator

142 in the operative phases of the facility, and should not be interpreted as the overall impact of

143 the facility on the local household prices. As demonstrated by Kiel and McClain (1995a), the

144 construction stage, which usually last several years, has a significant impact on property values.

145 Finally, each of the three EfW plants chosen for the study was on the sites of previous

146 incinerators. Although each of these decommissioned facilities had been offline before the

147 planning and construction of the new plant took place, a significant habituation effect

148 (Havranek et al., 2009) might have affected the transaction prices and could explain why the

149 study was unable to detect any impacts. Fourthly, as already noted, this study did not control

150 for changes in neighbourhood characteristics and used the Land Registry dataset, which does

151 not include several housing characteristics.

152

153 3. Methods

154

$155 \quad$ 3.1. Site selection

156 
157 Site selection involved the identification of a range of incinerator plants that were

158 representative of overall waste treatment activity in the UK and had suitable characteristics for

159 the implementation of the HPM. Incinerator plants managing municipal solid waste were

160 identified from an initial set of 134 facilities in England and Wales. Facilities located further than

$1610.8 \mathrm{~km}$ from urban areas were excluded from the analysis as negative externalities are expected

162 only to be observed in close proximity to the source (Kiel and McClain, 1995a; Cambridge

163 Econometrics, 2003). Incinerators that burn waste from their own in-house processes were also

164 excluded. The remaining facilities were screened to exclude all sites with insufficient number of

165 housing transactions over the observed period (Havranek et al., 2009; Defra, 2013). Following

166 this filtering process, three incinerator facilities (Table 1 and Figure 1) were selected for

167 analysis.

168

169

\subsection{Data}

170 House price data were obtained from mortgage records between 1983 and 2014 held by Lloyds

171 Banking Group. The database holds records describing the transaction price and property

172 characteristics for over 6 million transactions. These were matched to annual ACORN (A

173 Classification Of Residential Neighbourhoods) geo-demographic segmentation records of the

174 UK population ( $\mathrm{CACl}, 2006)$. To ensure the negative externalities of the incinerator were

175 quantified accurately, only houses within an 8km radius from the plant were included in line

176 with Kiel and Mclain (1995a) and Cambridge Econometrics (2003). House selection was plotted

177 within a Geographical Information System (GIS) environment (ArcGIS version 9.3; ESRI Inc.). 
178 Selected transactions were divided into incinerator planning, construction and operational

179 phases (Table 1) to assess the negative externalities within each of these phases.

180

\subsection{Analytical framework}

182

HPM models generally focus on five main house descriptors as defined by Malpezzi (2003): (i) geographical location; (ii) neighbourhood characteristics; (iii) property structural characteristics;

(iv) contract arrangements and additional conditions affecting price; and (v) the date of the transaction.

The basic statistical approach to HPM is a simple linear regression model (Eq. 1).

where $\boldsymbol{P}$ is the dependent variable price (i.e. house price), $\boldsymbol{X}_{\boldsymbol{i}}$ are a set of independent variables describing the price (e.g. house and incinerator characteristic), $\boldsymbol{n}$ is the total number of model parameters, $\boldsymbol{B}$ are the regression coefficients and $\boldsymbol{\varepsilon}$ is the error term. 
201 The functional form was selected after comparing the objective functions of linear, log-linear, 202 Box-Cox and quadratic models. For each site, models were independently fitted for the overall 203 data set as well as for each of the construction phases beforehand mentioned. Within each 204 phase, four regression models were fitted to test the negative externalities between 0-2km, 2$2054 \mathrm{~km}, 4-6 \mathrm{~km}$ and 6-8km from the incinerator. All models were fitted using Ordinary Least 206 Squares. To ease comparison between sites and ensure analytical consistency, all models were 207 fitted with the same initial list of independent variables (Table 2). The validity of the model 208 assumptions (i.e. multicolinearity, residual normality and homocedasticity) as well as presence 209 of specification errors was checked via residual analysis.

211 The monetary impact $(\boldsymbol{I})$ of incinerators on house prices per $100 \mathrm{~m}$ distance from incinerator 212 was quantified as follows:

216 where $\bar{P}_{2013}$ is the mean house price (2013 constant prices) calculated using the UK historic 217 Consumer Price Index (CPI) data (ONS, 2014) and $\beta_{\mathrm{d}}$ is the regression coefficient for variable 218 “distance to EfW" (D_EfW in Table 2).

\subsection{Results}




\subsubsection{Newhaven}

224 Newhaven is the model with the smallest sample of transactions $(2,958)$, which might impact

225 the overall reliability of the results of this particular model. The results indicate that during the

226 planning and construction phase all the statistically significant coefficients were positively

227 signed, suggesting that the incinerator had a positive impact on house prices (Table 3). Once

228 the EfW incinerator became operational the model suggests there were negative impacts on

229 the price of houses at $2-4 \mathrm{~km}$ from the site, but positive impacts on houses at $6-8 \mathrm{~km}$. Houses in

230 the 2-4km zone appear to be the only houses affected by negative impacts where the

231 incinerator reduced house prices by an average of $£ 2,277$ per house.

\subsubsection{Allington}

234 The model results for Allington (Table 4) suggests that proximity to the incinerator had a

235 negative impact on local house prices. During the planning phase there were negative impacts

236 at $2-4 \mathrm{~km}$ and $4-6 \mathrm{~km}$ during construction there were negative impacts at $4-6 \mathrm{~km}$ and $6-8 \mathrm{~km}$.

237 Once operational there was a negative impact only at $6-8 \mathrm{~km}$. According to the literature, the

238 strongest effect should be expected in close proximity to the incinerator. However, the nearest

239 residential area is at least $380 \mathrm{~m}$ from the incinerator. Hence the number of observations in the

$240 \quad 0-2 \mathrm{~km}$ model is significantly lower than the other zones. In monetary terms the negative

241 impacts during the planning phase at $2-4 \mathrm{~km}$ and $4-6 \mathrm{~km}$ were on average $£ 14,866$ (the largest

242 negative effect detected in this study) and $f 589$ per house respectively, while the impacts at 
243 construction at $4-6 \mathrm{~km}$ and $6-8 \mathrm{~km}$ were $f 562$ and $£ 1,405$ per house respectively. Once

244 operational the impact at $6-8 \mathrm{~km}$ was $£ 836$ per house.

$246 \quad 3.4 .3 \quad$ Marchwood

247 In all significant results ( $p$-value $<0.05$ ) in the planning stages (Table 5), proximity to Marchwood

248 EfW enhanced property prices, albeit by a relatively small margin. Furthermore, in the

249 construction phase there was a slight increase in house price at a distance of $2-4 \mathrm{~km}$. However,

250 model coefficients show that once operational the EfW site had a negative impact house prices

251 at $0-2 \mathrm{~km}$ of $£ 2,422$ per house.

252

$253 \quad$ 3.4.4 Collected results and aggregate impacts

254 Table 6 shows that the incinerator at Allington had the largest and most consistent negative 255 effect through the three stages of incinerator development and operation. The Newhaven and

256 Marchwood models have a broadly similar negative effect per house. Table 6 aggregates the 257 impact on price per house over the number of observed transactions to gauge the total impact 258 of the incinerator. The negative impact (externalities) of the Allington incinerator aggregates to $259 £ 22,651,116$. This is followed by the Marchwood incinerator at $£ 995,442$ then the Newhaven 260 incinerator with a negative impact of $£ 195,822$.

261

\section{Discussion}

263 With the exception of Allington the results show a number of significant positive coefficients, 264 which suggests the planning, construction and/or operation of the incinerator increased the 
265 value of houses within a specified distance of incinerators. There is nothing in our models that

266 can explain why house prices would increase as a result of the construction of an incinerator.

267 We can hypothesise that the increase in house prices could be associated with there being less

268 impact than local people expected. Thus the housing market response is positive after

269 construction or operation begins. However, it may also be possible that there are some

270 explanatory variables missing from the models, such as impact on employment.

271

272 Phillips et al. (2014) also found that three UK incinerators had no significant impact on local

273 house prices. The results from this current study in-part are supportive of Phillips et al. (2014),

274 although some statistically significant negative impacts were also detected. This may indicate

275 that the impacts of local incinerators on house prices are not necessarily negative under certain

276 conditions, counter to much previous literature. However, it is unclear what conditions support

277 positive, neutral or negative impacts. This is a current gap in the literature and provides a

278 fruitful area of future research. Given that there is nothing in our models to account for

279 positive impacts, henceforward we will only deal with the significant negative impacts.

280

281 The models of Allington, Newhaven and Marchwood show evidence of negative impacts from

282 the incinerators. However, there is little commonality across the results, which may be because

283 of the geographic differences between each incinerator and its surrounding area. All three

284 incinerators have been built on brownfield sites, but with different previous uses: 
- The Newhaven site is built in an industrial area on the banks of the tidal estuary of the River Ouse, over land formerly used as railway maintenance yard.

- The Marchwood incinerator is sited in an industrial area on the banks of Southampton Water, a tidal estuary characterised by areas of both residential and industrial development. In the proximity of the facility an incinerator was closed nine years before the current plant went online, but used as a waste transfer station for further ten years (Hampshire County Council, 2006) and demolished in 2012, further six years later (New Forest District Council, 2012).

- The Allington site was previously a stone quarry, with the incinerator being built within the quarry site and as such is mostly invisible from any residential structure. There is also a small industrial area, a reservoir and agricultural land in the proximity of the facility

The highest per house impact is found in Allington and aggregated over all transactions provides the largest negative impact from the three incinerators (Table 6). It is worth noting that the closest house to the incinerator at Allington is $380 \mathrm{~m}$ distant, which may have mitigated some of the largest impacts. Allington is the only site selected which was not the site of a previous waste management facility.

The Marchwood incinerator had the second largest impact on local house prices. Marchwood has been the site of a previous waste management facility and some habituation effect is to be expected. Marchwood also has a series of other potential sources of current nuisance. It is host 
to a large military port (built in 1943), a sewage treatment work (established in the 1960s), and a natural gas power station (established in 2009 and replacing a former power station from the 1960s) (New Forest District Council, 2004; Marchwood Power Limited, 2014). The sewage

treatment works, whose odour emissions are a major complaint of local residents (Marchwood Parish Council, 2012) might have an important role in hiding any negative externalities caused by the incinerator. Given this range of potential nuisance sources it is notable that the incinerator still had an additional negative effect.

The Newhaven incinerator had the third largest impact per house, although it was very similar to the per house impact at Marchwood. Newhaven also had the third highest aggregate impact, although there was a relatively small sample of transactions. The negative value is in line with the opposition shown by local residents to the incinerator. Newhaven has 12,000 residents, yet there were more than 16,000 objections to the development of the incinerator (van der Zee and Jones, 2012).

It is useful to compare the results with the literature. In terms of studies that have estimated the negative impacts of incinerators, Pragnell (2003) found that in postcode sectors containing EfW incinerators average house prices are 18 percent lower than house prices at $2.8 \mathrm{~km}$ from EfW sites. The results in this study show that the impacts are much lower than suggested by Pragnell (2003), although our model suggests that prices decreased in Allington by $10 \%$ in the planning phase at 2-4km), but greater than those estimated by Havranek et al. (2009), who found that households were willing to pay $£ 3.69$ for a $50 \%$ reduction in incinerator chimney 
330 size, $£ 2.12$ for a $50 \%$ reduction in odour, $£ 5.86$ for a $50 \%$ reduction in traffic. Phillips et al.

331 (2014) reported that the Marchwood EfW plant had no statistically significant impact on house

332 prices within $5 \mathrm{~km}$ of the incinerator, whereas this current study found that the Marchwood

333 incinerator had reduced the average house price within $2 \mathrm{~km}$ of the incinerator by $1.3 \%$.

335 The figures from Table 6 are generally (with the exception of Allington) within the estimated

336 costs of negative externalities of landfill sites. Cambridge Econometrics (2003) found that on

337 average, across the UK, operational landfills reduce the price of houses within 0.25 miles by

338 approximately $£ 5,500$ and about $£ 1,600$ for those between 0.25 and 0.5 miles. It is notable that

339 the impact of incinerators is detected at a greater range than that suggested by Cambridge

340 Econometrics (2003) and in line with other literature looking at the disamenties of incinerators.

341

342 The study by Cambridge Econometrics (2003) treated the impacts of landfill on the surrounding

343 area as 'stock disamenities', meaning that these impacts occur from the very existence of the

344 landfill and are independent of the size or type of waste facility. The results of this current

345 study suggests that the impacts of incinerator vary by site, so the use of stock disamenity as an

346 indicator of impact may be less useful for the analysis of the impacts of incinerators than it is

347 for landfill.

348

349 UK planning regulations require incinerators to be sited near the source of waste, but also in a

350 location that minimises the impacts of negative externalities. The incinerators studied were on

351 brownfield sites, which are perceived to have lower impacts than incinerators on virgin sites. 
352 The results show that despite this careful siting, there is a still a detectable impact in the

353 operational phase of the incinerator. In Marchwood there is an impact in the immediate vicinity

354 of the incinerator, despite the fact that there is likely to be a habituation effect from an older

355 incinerator. The impacts at Newhaven were experienced at $2-4 \mathrm{~km}$ from the incinerator and

356 even further out at Allington (6-8km). For Allington there are very few houses to impact upon

357 within $2-4 \mathrm{~km}$. The largest negative effect is experienced at $6-8 \mathrm{~km}$; again we can speculate that

358 this may because negative impacts were unanticipated at this distance. In Newhaven the

359 impact was again beyond the $0-2 \mathrm{~km}$ range, suggesting that similarly to Allington, the impact of

360 the incinerator has been largely mitigated at close proximity, but there have been

361 unanticipated impacts further away.

362

363 Therefore, the findings broadly support the hypothesis that careful siting of incinerators

364 minimises the social impacts (as indicated by house price changes), based on the evidence that

365 (apart from Marchwood) there were no impacts in the immediate vicinity of the incinerator.

366 However, it appears that there is a need for extra measures in terms of minimising nuisance

367 beyond the immediate proximity $(0-2 \mathrm{~km})$ of the incinerator. It should be noted that the largest

368 effect was experienced in the planning phase of the Allington incinerator. Section 1 highlighted

369 that there are usually large protests when a new incinerator is planned. As Allington had no

370 previous history of waste management it can be speculated that residents had serious concerns

371 about the potential impacts of the incinerator in the planning phase.

372 
373 It should be noted that this study did not analyse the benefits of waste incineration, nor did it

374 assess the negative impacts of alternative sites that could have been used for the four

375 incinerators considered. In this way we have valued negative externalities, rather than

376 determine the net social costs of these incinerators.

377

378 The results of this study should be treated with caution. For instance, there is no consideration

379 of prevailing wind in these models, nor surface features. Many of the impacts associated with

380 incinerators depend on wind direction and also whether any natural barriers, such as

381 woodlands or mountains separate source and receptor. This may have played a part in our

382 results. It is possible for an incinerator to be in close proximity to dwellings, but have low

383 impact because of prevailing wind and intervening geographic features (such as hills). Indeed,

384 to our knowledge, the impact of geographical features and meteorological conditions has not

385 been considered. This is grounds for further research.

387 Conclusions

388 This paper uses the Hedonic Pricing Method, utilising 55,000 transactions over a 20 year period

389 to quantify the impact of four EfW incinerators in England, which have been sited on previously

390 industrialised land. Broadly the results show inconsistent impacts across the stage of

391 development (planning, construction or operation) and distance from incinerator. In this way

392 the impacts of incineration appear to be different from those of landfill, which is often treated

393 as a stock disamenity (Cambridge Econometrics, 2003), so that individual analysis of

394 incinerators should be undertaken individually rather than aggregated. 
396 The results show a number of significant positive coefficients, which suggests some incinerators 397 have increased the value of houses within a specified distance. There is nothing in our models 398 that can explain why house prices would increase as a result of the construction of an 399 incinerator and so this study focuses on the significant negative impact. The cause of the 400 positive coefficients was hypothesised to be where impacts were less severe than expected, 401 causing prices to increase. This represents grounds for further research.

403 Each of the incinerators studied was sited in previously industrialised land to minimise the 404 impact on local residents. To an extent this was achieved. In two out of the three incinerators 405 there were no significant negative impacts detected within $2 \mathrm{~km}$ of the incinerator. This 406 suggests that careful siting of incinerators reduced the impact on residents. However, negative 407 impacts occurred in areas further afield, suggesting more can be done to minimise the impacts 408 of incinerators. At the Marchwood incinerator there was a significant negative impact within $4092 \mathrm{~km}$ of the incinerator, despite this area previously hosting a now defunct incinerator. The 410 largest negative impact was in the planning phase of the Allington incinerator, where the land 411 was previously used for quarrying, unconnected to municipal waste management. It appears 412 that the perceived impacts of an incinerator negatively impacted local property prices.

414 Once operational, the impact of the incinerators studied ranged from approximately $0.4 \%$ of 415 the mean house price to $1.3 \%$. These estimates fall in between the highest and lowest 416 estimates from the literature. The highest impact (of an operational incinerator) per house is at 
417 Marchwood (1.3\% of the mean 2013 house price for the area). However, this differs from the

418 results of Phillips et al. (2014), who using the repeated sales method found the incinerator had

419 no significant negative impact on nearby households. Although the impact is a small proportion

420 of total house sale value, the total negative impact of incinerators on their local communities to

421 date have been estimated as $£ 22,651,116$ for Allington followed by the Marchwood incinerator

422 at $£ 995,442$ then the Newhaven incinerator with a negative impact of $£ 195,822$.

423

424 The study of the economic impacts of waste management disamentities could be better

425 understood by including environmental factors, such as local topography and prevailing wind

426 direction. We also hypothesise that expected impacts relative to actual impacts could have a

427 large influence on the results of a hedonic pricing study of incinerators.

428

429 Acknowledgements

430 We would like to thank Nitesh Patel at Lloyds Banking Group for kindly providing the data for

431 this study and the Cranfield University IT service Unit for facilitating safe transfer and storage of

432 the data following Information Commissioners Office's code of practice. We would also like to

433 thank Phil Longhurst at Cranfield University for his helpful comments on the development of

434 this paper.

435

436 References

437 BBC, 2012. Protest over Gloucester waste incinerator scheme. http://www.bbc.co.uk/news/uk-

$438 \quad$ england-gloucestershire-19784319 (accessed 19/4/2015). 
439 BBC, 2013. Barnfield incinerator public inquiry opens to protests

440 http://www.bbc.co.uk/news/uk-england-beds-bucks-herts-24020242 (accessed 19/4/2015).

441 BBC, 2015. Javelin Park waste incinerator: Hundreds attend protest march. http://www.bbc.co.uk/news/uk-england-gloucestershire-30866217 (accessed 19/4/2015).

$444 \quad \mathrm{CACl}, 2006$. The ACORN User Guide.

445 http://acorn.caci.co.uk/downloads/Acorn-User-guide.pdf. (accessed 19/4/2015).

446 Cambridge Econometrics, 2003. A study to estimate the disamenity costs of landfill in Great Britain. http://webarchive.nationalarchives.gov.uk/20130402151656/http:/archive.defra.gov.u k/environment/waste/strategy/legislation/landfill/documents/landfill disamenity.pdf (accessed 19/4/2015). http://ec.europa.eu/environment/waste/studies/pdf/econ_eva landfill_report.pdf (accessed 19/4/2015). 43/1876202.pdf (accessed 19/4/2015).

458 Deaton, B., Hoehnb, J., 2004. Hedonic analysis of hazardous waste sites in the presence of other 459 urban disamenities. Environ. Sci. Policy. 7 (6), 499-508. 
https://www.gov.uk/government/uploads/system/uploads/attachment data/file/221036/pb13 889-incineration-municipal-waste.pdf (accessed 19/4/2016).

Defra, 2014. Energy from waste: A guide to the debate. HMSO, UK. https://www.gov.uk/government/uploads/system/uploads/attachment data/file/284 612/pb14130-energy-waste-201402.pdf (accessed 19/4/2015).

Eshet, T., Ayalon, O., Shechter, M., 2005. A critical review of economic valuation studies of externalities from incineration and landfilling. Waste Manage. Res. 23 (6), 487-504.

European Union, 2008. DIRECTIVE 2008/98/EC OF THE EUROPEAN PARLIAMENT AND OF THE COUNCIL on waste and repealing certain Directives. http://eur-lex.europa.eu/legal-content/EN/TXT/?uri=uriserv:ev0010 (accessed 19/4/2015).

Hampshire County Council, 2006. Minerals and waste sites in Hampshire 2003/2004. http://www3.hants.gov.uk/Ipar 03-04 appendix 2.pdf (accessed 19/4/2015).

Havranek, M., Liston, S., Rabl, A., Scasny, M., Taylor, T., Walton, H., Xingshu, Z., Zoughaib, A., 2009. Final report on waste management externalities in EU25 and report on disamenity impacts in the UK. http://www.feemproject.net/exiopol/M36+/EXIOPOL PDII 5 b-2.pdf (accessed 19/4/2015).

HPA, 2009. The Impact on Health of Emissions to Air from Municipal Waste Incinerators. http://www.seas.columbia.edu/earth/wtert/sofos/HPA Incinerator Advice Sept 09.p df (accessed 19/4/2015).

Kiel, K., McClain, K., 1995a. House prices during siting decision stages: the case of an incinerator from rumor through operation. J. Environ. Econ. Manage. 28 (2), 241-255. 
483 Kiel, K., McClain, K., 1995b. The Effect of an Incinerator Siting on Housing Appreciation Rates. J.

484

485

486

487

488

489

490

491

492

493

494

495

496

497

498

499

500

501

502

503

504
Urban Econ. 37 (3), 311-323.

Kiel, K., Williams, M., 2007. The impact of Superfund sites on local property values: Are all sites the same? J. Urban Econ. 61 (1), 170-192.

Kohlhase, J., 1991. The impact of toxic waste sites on housing values. J. Urban Econ. 30 (1), 126.

Lancaster, K., 1966. A new approach to consumer theory. J. Polit. Econ. 74 (2), 132-157.

Malpezzi, S., 2003. Hedonic pricing models: a selective and applied review, in: O'Sullivan T., Gibb T., (Eds.), Housing Economics and Public Policy. Blackwell Science Ltd., London, pp. 67-89.

Marchwood Parish Council., 2012. Community Plan consultation responses.

http://www.marchwoodparishcouncil.org.uk/a/12/c/19 03 Report B.pdf (accessed 19/4/2015).

Marchwood Power Limited, 2014. Welcome to Marchwood Power.

http://www.marchwoodpower.com/ (accessed 19/4/2015).

New Forest District Council, 2004. New Forest District Coastal Management Plan.

http://www.newforest.gov.uk/media/adobe/1/1/CMPPartC11Zone11.pdf (accessed 19/4/2015).

New Forest District Council, 2012. Hampshire County Council.

http://www3.hants.gov.uk/new forest.pdf (accessed 19/4/2015).

OECD (2013). Repeat Sales Methods, in OECD, Handbook on Residential Property Price Indices. http://dx.doi.org/10.1787/9789264197183-8-en (accessed 19/4/2015). 
505 ONS (2015). Consumer Price Indices. Available at:

506

507

508

509

510

511

512

513

514

515

516

517

518

519

520

521

522

http://ons.gov.uk/ons/taxonomy/index.html?nscl=Consumer+Price+Indices (accessed 19/4/2015).

Phillips, K., Longhurst, P., Wagland, S., (2014). Assessing the perception and reality of arguments against thermal waste treatment plants in terms of property prices. Waste Manage. 34 (1), 219-225.

Pragnell, M., 2003. The Economic Impact of an EfW Incinerator in Newhaven. http://www.virginiawater.co.uk/protect/images/economic impact.pdf (accessed 19/4/2016).

Rabl, A., Spadaro, J., Zoughaib, A., 2008. Environmental Impacts and Costs of Solid Waste: A Comparison of Landfill and Incineration. Waste Manage. Res. 26 (2), 147-162.

UKWIN, 2015. Table of Potential, Existing and Prevented Incinerators

http://ukwin.org.uk/resources/table/ (accessed 19/4/2016).

Van der Zee, B., Jones, G., 2012. This is the end for Newheaven'- controversial incinerator fires up. The Guardian. $5^{\text {th }}$ July. http://www.theguardian.com/environment/2012/jul/05/newhaven-incinerator-opens. (accessed 19/4/2016) 
Table 1. Summary description of the four incinerator facilities selected to assess the impact of negative externalities on

526 house prices. Permitted capacity (tn) and tonnage incinerated correspond to values obtained for 2012. AT, MW and NH stand

527 for Allington, Marchwood and Newhaven, respectively.

\begin{tabular}{|l|l|l|l|l|l|l|l|}
\hline \multirow{2}{*}{ Incinera } & Permitted & Tonnage & \multicolumn{2}{l|}{ Phase } & \multicolumn{2}{l|}{ Previous land } & Location \\
\cline { 3 - 7 } & \multirow{2}{*}{ capacity } & incinerated & Planning & Construction & Operational & use \\
\hline AT & 500,000 & 419,402 & $1996-2002$ & $2003-2008$ & $2008-2014$ & Quarry & Maidstone \\
\hline MW & 210,000 & 206,700 & $1995-2001$ & $2002-2004$ & $2004-2014$ & Incinerator & Southampton industrial \\
\hline NV & 240,000 & 224,730 & $2001-2007$ & $2008-2011$ & $2011-2014$ & Rail \\
& & & & & & & maintenance \\
\end{tabular}


Table 2. Independent variables considered for inclusion in the Hedonic Pricing Model. Variables have been grouped into five categories based on Malpezzi (2003).

\begin{tabular}{|c|c|c|}
\hline Category & Variable & Description \\
\hline Dependent Variable & Transaction price & Transaction price in $f$ \\
\hline \multirow[t]{6}{*}{ Transaction time } & Transaction date & Date when the transaction took place \\
\hline & Pre 1919 & Household sold before 1919 (dummy variable yes/no) \\
\hline & 1919-1945 & Household sold between 1919 and 1945 (dummy variable yes/no) \\
\hline & $1945-1960$ & Household sold between 1945 and 196- (dummy variable yes/no) \\
\hline & $1960+$ & House sold after 1960 (dummy variable yes/no) \\
\hline & Year\# & $\begin{array}{l}\text { Dummy variables for each year there are existing records of houses } \\
\text { being sold }\end{array}$ \\
\hline Contract arrangement & Tenure & Freehold or leasehold \\
\hline \multirow{13}{*}{$\begin{array}{l}\text { Property structural } \\
\text { characteristics }\end{array}$} & NW & New household (dummy variable yes/no) \\
\hline & FT & Flat (dummy variable yes/no) \\
\hline & BLW & Bungalow (dummy variable yes/no) \\
\hline & DTC & Detached property (dummy variable yes/no) \\
\hline & SDTC & Semi-detached property (dummy variable yes/no) \\
\hline & TRC & Terraced property (dummy variable yes/no) \\
\hline & LIV & Number of livingrooms \\
\hline & BED & Number of bedrooms \\
\hline & BTH & Number of bathrooms \\
\hline & TLT & Number of toilets \\
\hline & $\mathrm{FCH}$ & Full central heating (dummy variable (yes/no) \\
\hline & $\mathrm{PCH}$ & Partial central heating (dummy variable yes/no) \\
\hline & $\mathrm{NCH}$ & No central heating installed (dummy variable yes/no) \\
\hline
\end{tabular}




\begin{tabular}{|c|c|c|}
\hline & NG & Number of garages \\
\hline & NGS & The number of garage spaces \\
\hline & GR & Garden (dummy yes/no). \\
\hline & $\mathrm{RCH}$ & Road charge liable (dummy variable yes/no) \\
\hline $\begin{array}{l}\text { Neighbourhood } \\
\text { characteristics }\end{array}$ & A & $\begin{array}{l}\text { Property is in Acorn zone A- wealthy investors (dummy variable } \\
\text { yes/no). }\end{array}$ \\
\hline & B & $\begin{array}{l}\text { Property is in Acorn zone B -prospering families (dummy variable } \\
\text { yes/no). }\end{array}$ \\
\hline & $\mathrm{C}$ & $\begin{array}{l}\text { Property is in Acorn zone } \mathrm{C} \text { - traditional money (dummy variable } \\
\text { yes/no). }\end{array}$ \\
\hline & $\mathrm{D}$ & $\begin{array}{l}\text { Property is in Acorn zone - young urbanites (dummy variable } \\
\text { yes/no). }\end{array}$ \\
\hline & $E, F, G$ & $\begin{array}{l}\text { Property is in Acorn zone E/F/G - middle-aged families } \\
\text { (comfortable), contented pensioners and families and individuals } \\
\text { looking to settle down. Middle aged comfort } € \text {, contented } \\
\text { pensioners (F) and settling down (G) (dummy variable yes/no). }\end{array}$ \\
\hline & $\mathrm{H}$ & $\begin{array}{l}\text { Property is in Acorn zone } \mathrm{H} \text { - moderate living (dummy variable } \\
\text { yes/no) }\end{array}$ \\
\hline & $\mathrm{I}, \mathrm{K}$ & $\begin{array}{l}\text { Property is in Acorn zone I/K - meagre means and impoverished } \\
\text { pensioners (dummy variable yes/no). }\end{array}$ \\
\hline & $\mathrm{J}$ & $\begin{array}{l}\text { Property is in Acorn zone J - inner city existence (low income singles } \\
\text { and couples, multi ethnic young singles renting flats, high rise } \\
\text { poverty dependent on welfare and poor young financially inactive } \\
\text { (dummy variable yes/no). }\end{array}$ \\
\hline $\begin{array}{l}\text { Location within the } \\
\text { market }\end{array}$ & House location & Postcode \\
\hline
\end{tabular}


531 
Table 3. Results obtained for the Hedonic Pricing Method (Lancaster et al., 1996) for the case study area of Newhaven. I is

533 the monetary impact of the incinerator on house prices estimated as in Eq. 3. $\left({ }^{*}\right)$ indicates statistically significant coefficients

534 (p-value <0.05). $\overline{\boldsymbol{P}}_{2013}$ is the mean house price in 2013 calculated using historic Consumer Price Index data (ONS, 2014). $\boldsymbol{\beta}_{d}$ is

535 the regression coefficient as described in Eq. 3 and $\mathbf{N}$ is the number of records included in the regression model. The F-test

536 for the overall model was statistically significant ( $p$-value $<0.05$ ).

\begin{tabular}{|c|c|c|c|c|c|}
\hline Phase & Distance (km) & $\mathbf{N}$ & $\beta_{d}$ & $\bar{P}_{2013}$ & I \\
\hline \multirow{4}{*}{ Planning } & $0-2 \mathrm{~km}$ & 380 & $0.000062^{*}$ & 210247 & 1304 \\
\hline & $2-4 \mathrm{~km}$ & 532 & 0.000021 & & \\
\hline & $4-6 \mathrm{~km}$ & 922 & $0.000035^{*}$ & 258307 & 904 \\
\hline & $6-8 \mathrm{~km}$ & 352 & $0.00018^{*}$ & 392859 & 7071 \\
\hline \multirow{4}{*}{ Construction } & $0-2 \mathrm{~km}$ & 84 & 0.000098 & & \\
\hline & $2-4 \mathrm{~km}$ & 139 & -0.000467 & & \\
\hline & $4-6 \mathrm{~km}$ & 191 & 0.000023 & & \\
\hline & $6-8 \mathrm{~km}$ & 54 & $0.000463^{*}$ & 336291 & 15570 \\
\hline \multirow{4}{*}{ Operational } & $0-2 \mathrm{~km}$ & 78 & 0.000045 & & \\
\hline & $2-4 \mathrm{~km}$ & 86 & $-0.000099^{*}$ & 230050 & -2277 \\
\hline & $4-6 \mathrm{~km}$ & 115 & 0.00004 & & \\
\hline & $6-8 \mathrm{~km}$ & 25 & $0.000221^{*}$ & 288800 & 6382 \\
\hline
\end{tabular}


Table 4. Results obtained for the Hedonic Pricing Method (Lancaster et al., 1996) for the case study area of Allington. I is the monetary impact of the incinerator on house prices estimated as in Eq. 3. (*) indicates statistically significant coefficients (p-

541 value $<0.05) . \bar{P}_{2013}$ is the mean house price in 2013 calculated using historic Consumer Price Index data (ONS, 2014). $\boldsymbol{\beta}_{d}$ is

542 the regression coefficient as described in Eq. 3 and $\mathbf{N}$ is the number of records included in the regression model. The F-test

543 for the overall model was statistically significant ( $p$-value $<0.05)$.

\begin{tabular}{|c|c|c|c|c|c|}
\hline Phase & Distance (km) & $\mathbf{N}$ & $\beta_{d}$ & $\bar{P}_{2013}$ & I \\
\hline \multirow{4}{*}{ Planning } & $0-2 \mathrm{~km}$ & 324 & 0.00001 & & \\
\hline & $2-4 \mathrm{~km}$ & 1162 & $-0.00101^{*}$ & 147190 & -14866 \\
\hline & $4-6 \mathrm{~km}$ & 1437 & $-0.00004^{*}$ & 147190 & -589 \\
\hline & $6-8 \mathrm{~km}$ & 1528 & -0.00001 & & \\
\hline \multirow{4}{*}{ Construction } & $0-2 \mathrm{~km}$ & 453 & 0 & & \\
\hline & $2-4 \mathrm{~km}$ & 2018 & 0.00001 & & \\
\hline & $4-6 \mathrm{~km}$ & 1915 & $-0.00002^{*}$ & 281088 & -562 \\
\hline & $6-8 \mathrm{~km}$ & 2089 & $-0.00005^{*}$ & 281088 & -1405 \\
\hline \multirow{4}{*}{ Operational } & $0-2 \mathrm{~km}$ & 109 & 0.00003 & & \\
\hline & $2-4 \mathrm{~km}$ & 576 & 0.00001 & & \\
\hline & $4-6 \mathrm{~km}$ & 556 & -0.00001 & & \\
\hline & $6-8 \mathrm{~km}$ & 621 & $-0.00004^{*}$ & 208876 & -836 \\
\hline
\end{tabular}


Table 5. Results obtained for the Hedonic Pricing Method (Lancaster et al., 1996) for the case study area of Marchwood. I is the monetary impact of the incinerator on house prices estimated as in Eq. 3. $\left({ }^{*}\right)$ indicates statistically significant coefficients (p-value <0.05). $\bar{P}_{2013}$ is the mean house price in 2013 calculated using historic Cobsumer Price Index data (ONS, 2014). $\beta_{d}$ is the regression coefficient as described in Eq. 3 and $\mathbf{N}$ is the number of records included in the regression model. The F-test

\begin{tabular}{|c|c|c|c|c|c|}
\hline Phase & Distance (km) & $\mathbf{N}$ & $\beta_{d}$ & $\bar{P}_{2013}$ & I551 \\
\hline \multirow{4}{*}{ Planning } & $0-2 \mathrm{~km}$ & 327 & $0.000129^{*}$ & 98450 & 1270 \\
\hline & $2-4 \mathrm{~km}$ & 1238 & 0 & & \\
\hline & $4-6 \mathrm{~km}$ & 2359 & -0.00001 & & \\
\hline & $6-8 \mathrm{~km}$ & 135 & $0.00003^{*}$ & 106966 & 321 \\
\hline \multirow{4}{*}{ Construction } & $0-2 \mathrm{~km}$ & 148 & -0.00004 & & \\
\hline & $2-4 \mathrm{~km}$ & 657 & $0.000052^{*}$ & 200254 & 1041 \\
\hline & $4-6 \mathrm{~km}$ & 1040 & -0.00001 & & \\
\hline & $6-8 \mathrm{~km}$ & 613 & 0.00001 & & \\
\hline \multirow{4}{*}{ Operational } & $0-2 \mathrm{~km}$ & 411 & $-0.000133^{*}$ & 182141 & -2422 \\
\hline & $2-4 \mathrm{~km}$ & 1927 & 0.00001 & & \\
\hline & $4-6 \mathrm{~km}$ & 2992 & 0 & & \\
\hline & $6-8 \mathrm{~km}$ & 1843 & 0.000016 & & \\
\hline
\end{tabular}

\begin{tabular}{|c|c|c|c|c|c|c|c|}
\hline \multirow{2}{*}{ Phase } & \multirow{2}{*}{$\begin{array}{l}\text { Distance } \\
(\mathrm{km})\end{array}$} & \multicolumn{3}{|c|}{ Average economic impact per house (f) } & \multirow{2}{*}{$\mathrm{N}$} & \multirow{2}{*}{$\begin{array}{l}\text { Total impact on } \\
\text { house prices(f) }\end{array}$} & \multirow{2}{*}{$\begin{array}{l}\text { Percentage } \\
\text { of mean } \\
\text { house price }\end{array}$} \\
\hline & & Newhaven & Allington & Marchwood & & & \\
\hline
\end{tabular}




\begin{tabular}{|c|c|c|c|c|c|c|c|}
\hline & & & & & & & (\%) \\
\hline \multirow{2}{*}{ Planning } & $2-4 \mathrm{~km}$ & N/A & -14866 & N/A & 1162 & $-17,274,513$ & 10 \\
\hline & $4-6 \mathrm{~km}$ & N/A & -589 & N/A & 1437 & $-846,393$ & 0.4 \\
\hline \multirow{2}{*}{ Construction } & $4-6 \mathrm{~km}$ & N/A & -562 & N/A & 1915 & $-1,076,239$ & 0.2 \\
\hline & $6-8 \mathrm{~km}$ & N/A & -1405 & N/A & 2089 & $-2,935,045$ & 0.5 \\
\hline \multirow{3}{*}{ Operational } & $0-2 \mathrm{~km}$ & N/A & $\mathrm{N} / \mathrm{A}$ & -2422 & 411 & $-995,442$ & 1.3 \\
\hline & $2-4 \mathrm{~km}$ & -2277 & $\mathrm{~N} / \mathrm{A}$ & N/A & 86 & $-195,822$ & 1 \\
\hline & $6-8 \mathrm{~km}$ & $\mathrm{~N} / \mathrm{A}$ & -836 & $\mathrm{~N} / \mathrm{A}$ & 621 & $-519,156$ & 0.4 \\
\hline
\end{tabular}

556

557 
Figures

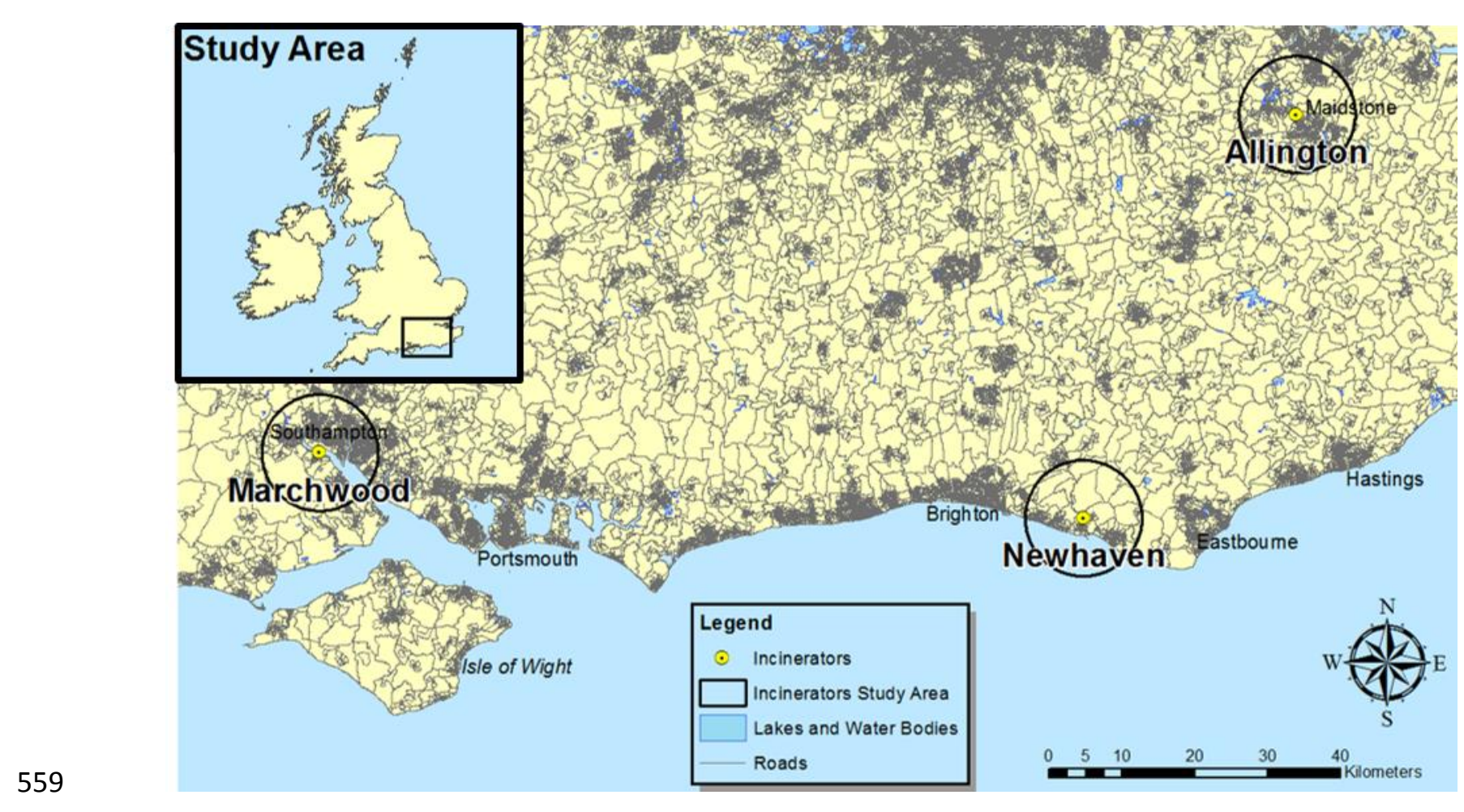

560

Figure 1: study areas selected for analysis. 


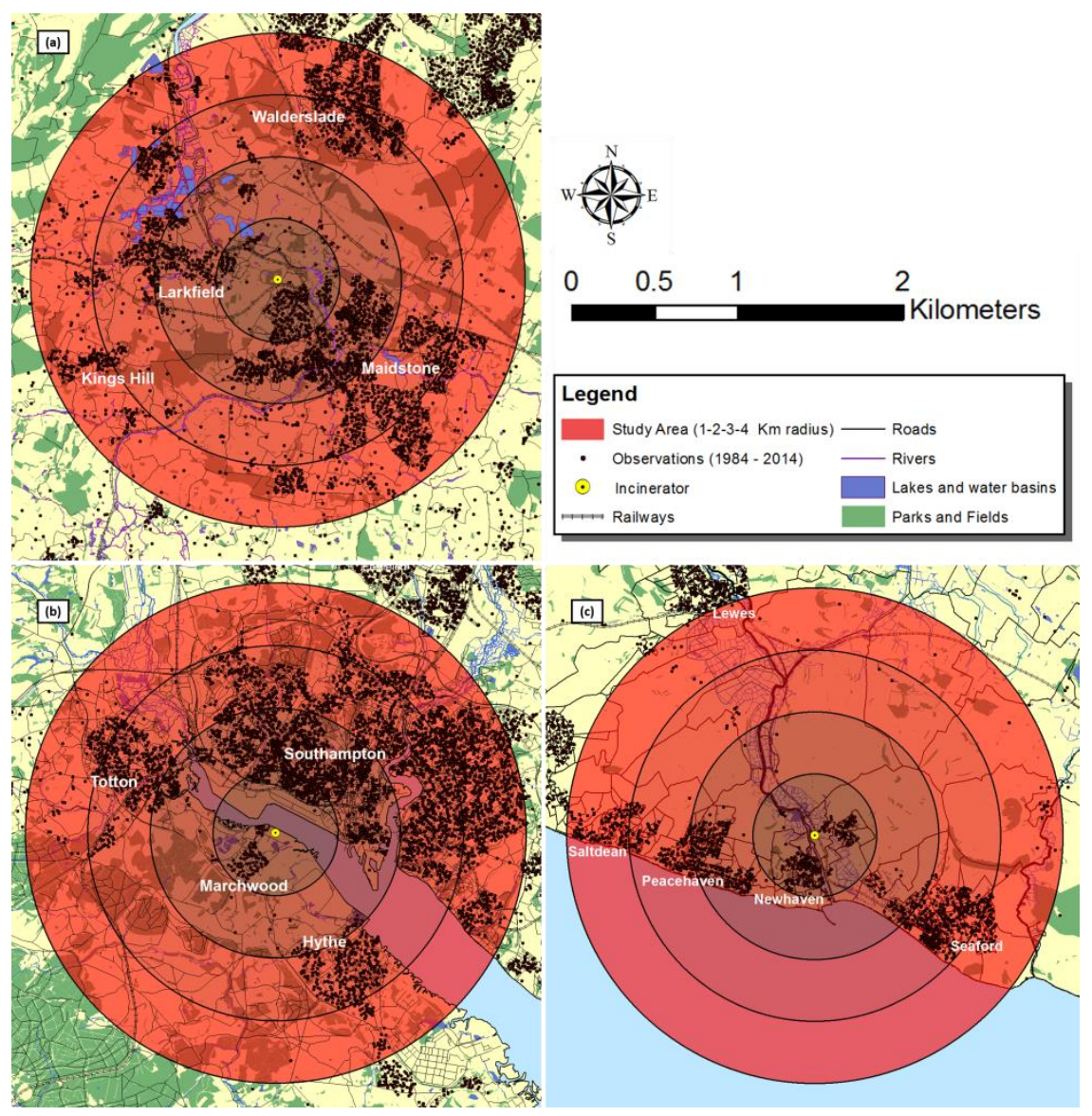

562

Figure 2: Detailed map showing the houses selected for analysis falling within a $2 \mathrm{~km}, 4 \mathbf{k m}, 6 \mathrm{~km}$ and $8 \mathrm{~km}$ radius for the sites at (a) Allington, (c) Marchwood and (d) Newhaven. 